17. Comparison of Indomethacin, Diclofenac and Aspirin-Induced Gastric Damage according to Age in Rats / P. J. Seo [et al.] // Gut Liver. - 2012. - Vol. 6, № 2. - P. 210-217.

18. Nonsteroidal anti-inflammatory drug-activated gene-1 plays a role in the impairing effects of cyclooxygenase inhibitors on gastric ulcer healing / R. Colucci [et al.] // J Pharmacol Exp Ther. - 2012. - Vol. 342, № 1. P. 140-149.

Маркевич Анна, Вирченко Александр, Фалалеева Татьяна, Кудрявцев Костянтин, Береговая Татьяна. Профиль сывороточных цитокинов у крыс с экспериментальным язвообразованием на фоне лечебного введения пролинсодержимого соединения. Целью работы было изучение терапевтических свойств низкомолекулярного органического соединения 2-(2-гидроксифенокси) ацетил)-L-пролината натрия при язвообразовании в желудке крыс, вызванном стрессом, этанолом, нестероидными противовоспалительными средствами (индометацином и аспирином). Исследуемое вещество вводили в дозе 1 мг/кг трижды на протяжении троих суток после ульцерогенного стимула. Установлено значительное ускорение заживления слизистой оболочки желудка крыс под влиянием используемого средства. Антиязвенные свойства соединения были ассоциированы с уменьшением содержания прововоспалительных цитокинов в крови и увеличением содержания антивоспалительных цитокинов и простагландина Е2.

Ключевые слова: 2-(2-гидроксифенокси) ацетил)-L-пролинат натрия, язва желудка, цитокины, простагландин E2.

Markevich Anna, Virchenko Oleksandr, Falalyeyeva Tetyana, Kudryavtsev Kostyantun, Beregova Tetayna. Profile of Serum Cytokines in Rats with Experimental Ulceration in the Conditions of the Therapeutic Administration of Proline Containing Compound. The purpose was to study the therapeutic properties of the low molecular weight organic compound sodium 2-(2-hydroxyphenoxy) acetyl)-L-prolinate in the conditions of gastric ulceration in rats caused by stress, ethanol, non-steroidal anti-inflammatory drugs (indomethacin and aspirin). The test substance is administered in a dose of $1 \mathrm{mg} / \mathrm{kg}$ three times for three days after the ulcerogenic stimulus. It was established a considerable acceleration of the gastric mucosa healing of rats under the influence of studied compound. Its antiulcer properties was associated with a decrease of the proinflammatory cytokines content in blood and increase of the content of anti-inflammatory cytokines and prostaglandin E2.

Key words: sodium 2-(2-hydroxyphenoxy) acetyl)-L-prolinate, gastric ulcer, cytokines, prostaglandin E2.

Стаття надійшла до редколегії 11.02.2015 p.

UDC:599.323.41:577.353

\author{
Olexiy Melnychuk \\ Olexandr Motuziuk \\ Svitlana Shvayko \\ Svitlana Zay
}

\title{
Progressive fatigue dynamic development of isolated natively musculus gastrocnemius medialis in alcoholic rats
}

In this article was investigated the development progressive fatigue dynamic of isolated natively musculus gastrocnemius medialis during tetanic contraction in alcoholic rats $(n=15)$. Registration of tetanic contraction of the isolated muscular preparation was registered in the isometric mode, during it's direct electric stimulation. The results of research shows the absence of significant changes in isolated natively musculus gastrocnemius medialis development progressive fatigue in alcoholic rats, in comparison to intact animals.

Key words: alcohol intoxication, alcoholic rats, muscle fatigue, musculus gastrocnemius.

Introduction. The skeletal muscles continuously adapt to the changes of it's environment by the way of gene expression and stability of protein modifycation, which influence on a physiological function and muscles mass. However, usually, mechanical stress goes out outside of muscles adaptation possibilities and causes their sharp damage.

(C) Melnychuk O., Motuziuk O., Shvayko S., Zay S., 2015 
Relatively the superficial location of many muscles does them vulnerable to the sharp damages as a result of influence of extremal temperatures, hammering, breaks and toxins action [14].

One of the most widespread factors of unfavorable influence on organism there is alcohol. According to official statistics, is observed stably high alcohol-dependent people part in the population structure of different countries worldwide $[13 ; 16]$. Thus, it's noticeable tendency to the increase of quantity of this social association [16].

The alcohol abuse causes to the development of skeletal muscle alcoholic myopathy [10], which causes serious biochemical and patho-physiologycal atrophy changes of the striated skeletal muscles tissue $[10 ; 8]$ and burdens the functional muscle state $[6 ; 9]$.

In general, alcoholic myopathy develops independently to the other displays of alcoholic desease [2]. Within the alcoholic desease framework are distinguished two basic forms of skeletal muscles alcoholic damage: sharp and chronic alcoholic myopathy [10]. Sharp alcoholic myopathy is diagnosed in $1-5 \%$ clinical incidents [3], but the chronic alcoholic myopathy - is mostly diagnosed (40-60\%) clinical form of alcoholic myopathy [10].

Today, the alcohol-associated striated skeletal muscles damage remains the less investigational problem within the alcoholic illness framework [1].

Thus, the investigated aim is to analyse the development progressive fatigue dynamic of isolated natively musculus gastrocnemius medialis $(M G M)$ during tetanic contraction in alcoholic rats.

Methods. The experiments were carried out on 30 five months old male Wistar rats that were kept in standard conditions and on diet typical for vivarium: alcoholic rats $(\mathrm{n}=15, \mathrm{~m}=148,43 \pm 11,08 \mathrm{~g})$, intact rats $(\mathrm{n}=15, \mathrm{~m}=150,83 \pm 8,18 \mathrm{~g})$.

The experiment protocol was established by Lesia Ukrainca Eastern European National University Bioethics Commission according to the international principles of European Convention for the Protection of Vertebrate Animals used for Experimental and Other Scientific Purposes (Strasbourg, 1986) and bioethics norm, according to the Ukraine Low №: 3446-IV 21.02.2006 p., Kiev, “About animals protecting from legal cruelty" with realization of medical-biology researches.

The experiments were carried out in two stages: chronic experiment (30-day alcohol intoxication) and acute experiment. All the experimental procedures and surgery manipulation were performed in aseptic and antiseptic conditions at the same time of day, with the aim of circadian rhythm effects avoidance.

In order to induce of chronic alcohol intoxication in rats, $40 \%$ ethyl alcohol (prepared by diluting 96\% ethyl alcohol (Bio-Farma Ltd., Ukraine) in distilled water) was delivered intragastrically through epidural catheter G18 («Bbraun», Germany) for 30 days in the dose of $2 \mathrm{ml}$ per $100 \mathrm{~g}$ of an animal's weight [5].

The animals were weighed once a week, with a weekly gain being about 7,11 $\pm 1,34 \mathrm{~g}$.

During preparation to the acute experiment, anesthesia was initiated by thiopentalum-natrium («ARTERIUM», Ukraine) (0,04 mg / $100 \mathrm{~g}$, supporting dose - 0,1 mg / $100 \mathrm{~g}$, administration rate - 5-10 ml / min) after preliminary premedication by $0,1 \%$ atropine with the aim to prevent from laryngospasm and bronchiospasm $(0,1 \mathrm{ml}$ of atropine $30 \mathrm{~min}$ before inducing narcotic sleep). The anesthesia duration was controlled by estimating the strength of flexor reflex of the hind limb with mechanical compression of big toe (hallux). Euthanasia was performed by cervical distribution.

In order to registration of MGM tetanic contraction, muscle was exposed and freed from the surrounding tissues. The anterior muscles of $m$. biceps femoris and $m$. semitendinosus were cut out; $m$. soleus, deep flexor muscles, fibular muscles and anterior tibial muscle were left intact but denervated by cutting $n$. peroneus comunnis and separating it's anterior branches (n. peroneus, $n$. tibialis and $n$. suralis).

The denervation was followed by open myotomy of $m$. gastrocnemius along the medial connecting line until intermuscular junctions of the muscle medial and lateral heads were completely split. Tenotomy of achilles tendon was performed by separating the tendon distal end of $M G M$ from the tendon distal end of $m$. plantaris. The tendon proximal end of MGM was separated from os femoris and facies articularis sesamoidea lat.

The isolated natively $M G M$ was fixed by mechanical clips in the plexiglass chamber of tensometric equipment filled with constantly circulating isotonic Tyrode's solution: $\mathrm{H}_{2} \mathrm{O}-100$ мл, $\mathrm{NaCl}-0,8$ г, $\mathrm{KCl}-$ $0,02 \Gamma, \mathrm{CaCl}_{2}-0,02 \Gamma, \mathrm{NaHCO}_{3}-0,02 \Gamma, \mathrm{Na}_{2} \mathrm{HPO}_{4}-0,005 \Gamma, \mathrm{MgCl}_{2}-0,01 \Gamma$, Glucose $-0.1 \mathrm{~g}, \mathrm{O}_{2}-$ saturation, $\mathrm{pH}-7,0$ [4], at $37 \pm 1{ }^{\circ} \mathrm{C}$. The proximal tendon end of $M G M$ was fixed by mechanical clamps motionlessly, the distal tendon was connected to a force transducer. The tetanic contraction of $M G M$ was 
registrated in isometric conditions by direct stimulation of the muscle via platinum electrodes (placed at the distance of $12 \mathrm{~mm}$ from each other) by rectangular pulses (duration time $-0,1 \mathrm{~ms}$, frequency $-50 \mathrm{~Hz}$, voltage $-2 \mathrm{~V}$ ). The stimulation signal lasted for three seconds, indifferent period (muscle inactivity period in intervals between stimulation patterns) was $5 \mathrm{~min}$.

The force of isometric contraction was registered by force transducer. The force transducer was connected with an amplifier and ADC complex. The analog signal from the force transducer was input into two-channel ADC («Iris USB-Oscilloscope», Ukraine) with 10 bits resolution and discretion frequency 1 $\mathrm{kHz}$. The output voltage was displayed on the oscilloscope monitor connected to computer by appropriate software. Amplitude range of entrance signals is: $0-2 \mathrm{~V}, 2-20 \mathrm{~V}$. entrance signal tension scale scope is $0,3-$ 2 Volt / Screen. Quantum error - 0,0039 V.

For characteristic of development progressive fatigue dynamic of isolated natively $M G M$ was calculated dynamic change of tetanic force $\left(F_{t e t}\right)$ during experiment, medial loss $F_{t e t}$ in each successive tetanus (Ftet in \%, was calculated as a ratio of the maximum tetanus amplitude in $\mathrm{mV}$ to isoline) and Fatigue Index $(F I)$ [7], which we calculated by alternative method.

The experimental results were processed by the methods of variation statistics using Statistica 8.0 ("StatSoft", USA). The samplings were tested with respect to normally distributed general summations by using Shapiro-Wilk criterion. To determine probable differences between the average values of the samplings, Mann-Witni U-criterion was used. The differences were considered reliable at $\mathrm{p} \leq 0.05$. The results are presented as arithmetical mean \pm error of the average $(\mathrm{M} \pm \mathrm{m})$, and is given the number of tests $(\mathrm{n})$.

Results and discussion. The analysis of research results showed that in alcoholic rats the time course of tetanus during experiment are not significantly changes, in comparison to intact rats (fig. 1).
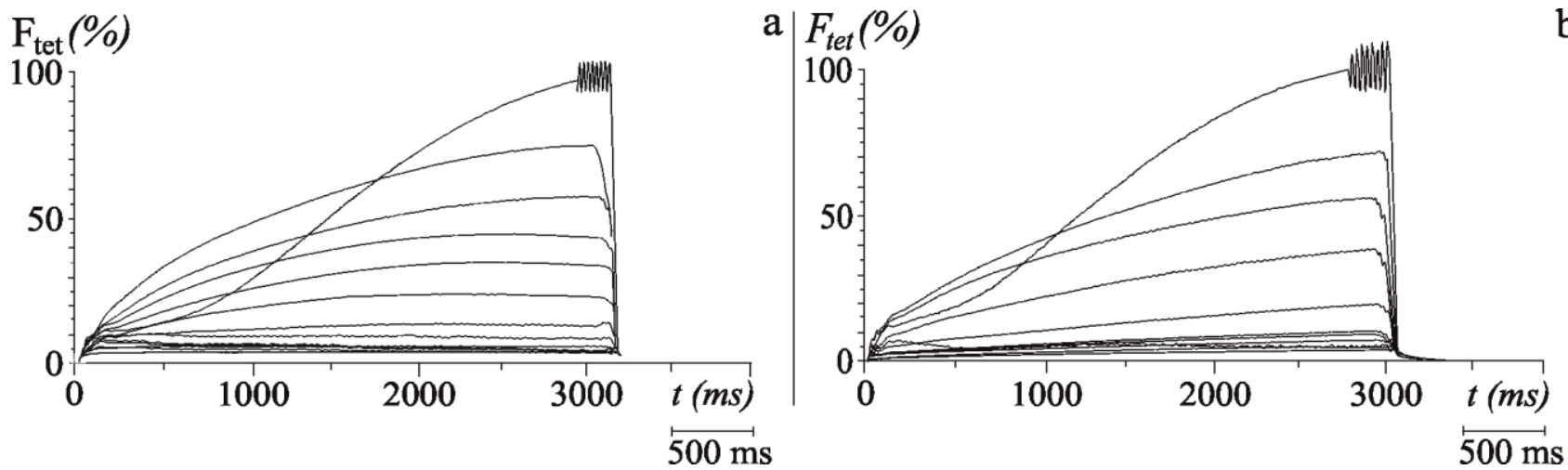

Fig. 1. Time course of tetanus during experiment in intact rats $-\mathbf{a}(\mathbf{n}=15)$ and alcoholic rats $-\mathbf{b}(\mathbf{n}=15)$.

$F_{t e t}$ - tetanic force in \% (was calculated as a ratio of the maximum tetanus amplitude in $\mathrm{mV}$ to isoline). $t$ (time) $(\mathrm{ms})-$ uac.

In intact and alcoholic rats the development progressive fatigue dynamic of isolated natively $M G M$ develops with identical intensity (fig. 2. a - b; fig. 3. a). However, we detected the significant differences in the development progressive fatigue dynamic of isolated natively $M G M$ in alcoholic rats, in comparison to intact animals in 2, 4 and $8-12$ tetanus $(\mathrm{p} \leq 0,05)$ (fig. 2. a), simultaneously with the increase of isolated native $M G M \mathrm{~F}_{\text {tet }}$ losses in 2, 5 and 9 tetanus $(\mathrm{p} \leq 0,05)$ (fig. $\left.2 . \mathrm{b}\right)$. 

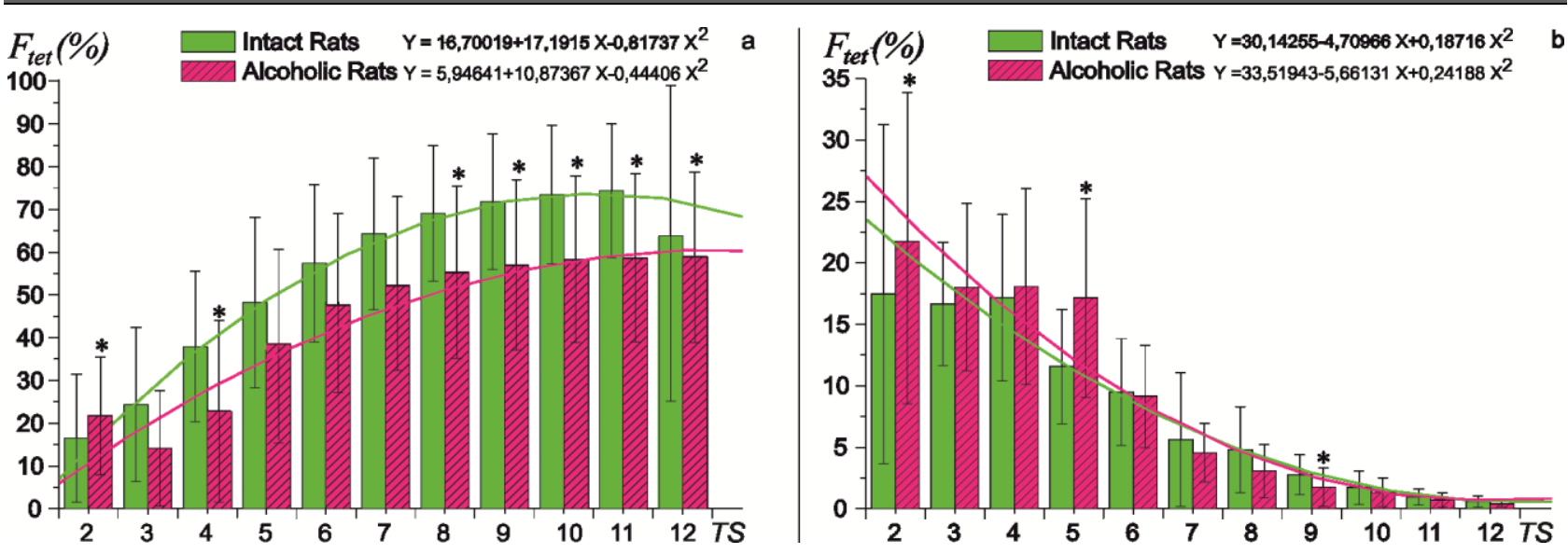

Fig. 2. a - the development progressive fatigue dynamic of isolated natively $M G M$ in intact $(n=15)$ and alcoholic rats $(n=15) ; b$ - isolated natively $M G M F_{\text {tet }}$ loss in intact and alcoholic rats in each successive tetanus during experiment (first tetanus is not demonstrated, because accepted for 0 starting point). $F_{t e t}-$

Tetanic Force. TS - Tetanic Sequence. * $-(\mathbf{p} \leq \mathbf{0 , 0 5})$ in alcoholic rats in comparison to intact animals.

Thus, the significant differences in the development progressive fatigue dynamic of isolated natively $M G M$ and greater $F_{\text {tet }}$ loss $(21,73 \pm 13,82 \%)$ in 2 tetanus in alcoholic rats, in comparison to intact animals, specify on speed-up muscular fatigue development in alcoholic rats.

However, the significant differences in the development progressive fatigue dynamic of isolated natively $M G M$ in alcoholic rats, in comparison to intact rats (fig. 2. a) are not confirmed by the values of fatigue index (FI) (fig. 3. a), which was calculated by alternative method. It allows us to assert confidently about absence of significant differences in the development progressive fatigue dynamic of isolated natively $M G M$ in alcoholic rats, in comparison to intact rats. In this case, the significant differences in FI of alcoholic rats, in comparison to intact rats, were detected only in 5 tetanus, that also coincides with the greater $F_{\text {tet }}$ loss of isolated natively $M G M$ in this tetanus in alcoholic rats (fig. 2. b).
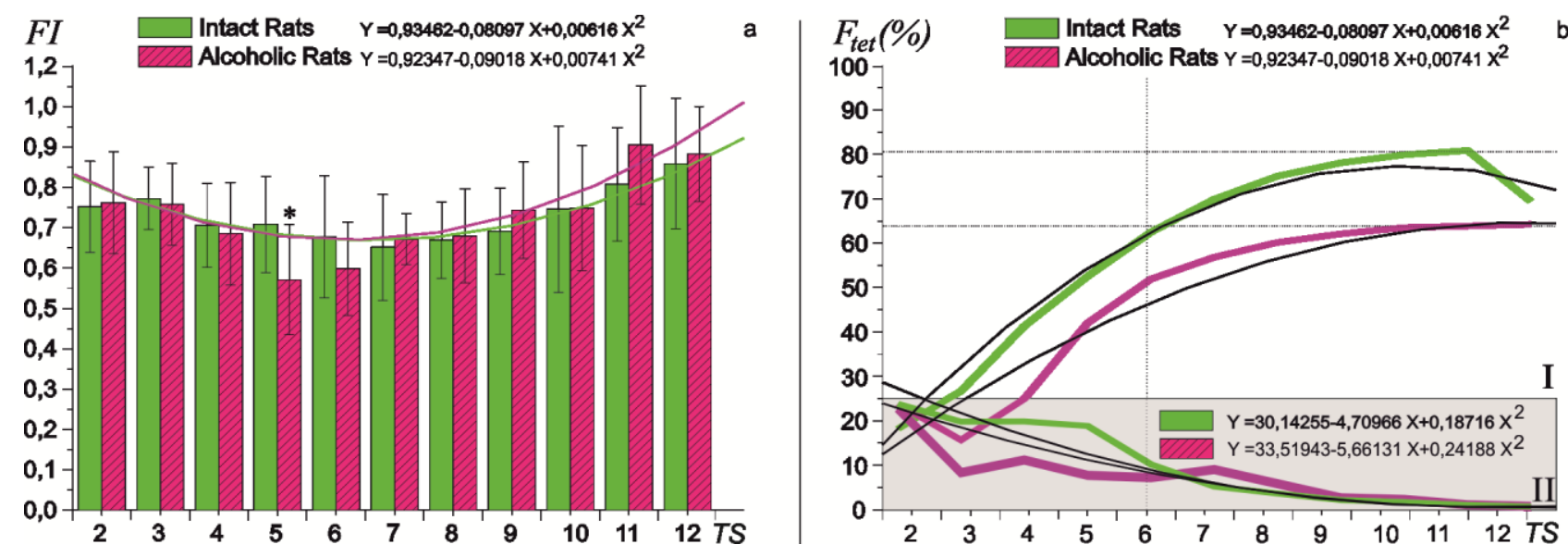

Fig. 3. a - Fatigue Index (FI) of isolated native $M G M$ in intact rats $(n=15)$ and alcoholic rats $(n=15)$; $b$ - schematic image of the development progressive fatigue dynamic (I) and $F$ tet loss in each tetanus during experiment (II) of isolated natively MGM in intact and alcoholic rats during experiment (first tetanus is not demonstrated, because accepted for 0 starting point). $F_{\text {tet }}-$ Tetanic Force. TS - Tetanic Sequence. $*_{-}(\mathbf{p} \leq \mathbf{0 , 0 5})$ in alcoholic rats in comparison to an intact animals.

Thus, the research results demonstrate, that development progressive fatigue dynamic of isolated natively $M G M$ in intact and alcoholic rats is characterized by asymmetry of $F_{t e t}$ loss intensities during experiment and muscle $F_{\text {tet }}$ loss in every tetanus (fig. 3. b).

The increasing of isolated natively $M G M F_{\text {tet }}$ loss in intact and alcoholic rats, which achieves it's maximal values in the second half of experiment (fig. 2. a), accompanied by the simultaneous diminishing of muscle $\mathrm{F}_{\text {tet }}$ loss in each tetanus, during experiment. 
Thus, the demonstrated asymmetric development progressive fatigue dynamic of isolated natively $M G M$ in intact and alcoholic rats, in general, identically intensive, what the FI values testify, and is described by a parabolic function with a clear right-side trend (fig 3. a).

Deserves attention the fact that the detected significant differences of development progressive fatigue dynamic of isolated natively $M G M$ in intact and alcoholic rats in 2, 4 and 8-12 tetanus, in comparison to non-alcoholic rats (fig. 2. a), are not confirmed by the expected $F I$ values. We explain it by the difference of tetanic peak amplitudes of isolated natively $M G M$ in intact and alcoholic rats, that also explains the detected significant muscle $F_{\text {tet }}$ loss increase in alcoholic rats in 2 and 5 tetanus (fig. 2. b) (confirmed of FI in 5 tetanus), in comparison to intact rats.

Tetanic peak amplitudes difference of isolated natively MGM in alcoholic rats, in comparison to intact rats, we explain by alcohol-associated atrophy of anaerobic myofibrils [12], which involves the depletion of muscle proteins (myosin, desmin, actin and troponin, as well as netin and nebulin) and their less intensive synthesis

The interpretations disparity in relation to the development progressive fatigue dynamic of isolated natively $M G M$ in intact and alcoholic rats, on the basis of parameters results, used by us for it's analysis, we explain by difference of methodological approaches.

In the first case (fig. 2. a), for the estimation of development progressive fatigue dynamic of isolated natively $M G M$ in intact and alcoholic rats, we used the gradient of isolated natively $M G M \mathrm{~F}_{\text {tet }}$ change values during experiment ( 0 counting point out -1 tetanus), in the second (fig. 2 . b) - the same gradient, however, 0 counting point out - every previous tetanus).

Thus, the results based on the difference of isolated natively $M G M F_{\text {tet }}$ values in the different points of experiment, which are correlated as $n$ (every next tetanus in experiment) to $l_{t \text { (tetanus) }}\left(1\right.$ tetanus) and $n_{a \text { (actual) }}$ (every actual tetanus in the time moment of experiment) to $n$ (every previous tetanus in experiment): $n: 1_{t}$ and $n_{a}: n$, accordingly.

But, the estimation of development progressive fatigue dynamic of isolated natively $M G M$ in intact and alcoholic rats isolated natively on the basis of FI results, based on the result from the division of muscle $F_{\text {tet }}$ on the principle of $n_{a}: n$, that the best represents the internal development progressive fatigue dynamic of isolated natively $M G M$ in intact and alcoholic rats and allows adequately interpret the muscular development progressive fatigue dynamic.

Conclusion and further perspectives. Thus, the results of our research demonstrate, that the development progressive fatigue dynamic of isolated natively $M G M$ in intact and alcoholic rats is effectively described by the applied methodological approaches, however an adequate interpretation of analysis results is possible only on the basis of $F I$ values.

The research results showed that the development progressive fatigue dynamic of isolated natively $M G M$ in alcoholic rats, in comparison to intact rats, identically intensive and does not test significant changes.

This research is done by us within the research framework of ischemic skeletal muscles contractile dysfunction by alcohol-myotoxic burden in alcoholic rats. Thus, further researches perspectives in this direction provide the detailed isolated natively $M G M$ analysis mechanical characteristics in alcoholic rats. It will allow adequately explain the alcohol-myotoxic burden signs of ischemic-associated skeletal muscle dysfunction in alcoholic rats.

\section{Sources and literature}

1. Дамулин И. В. Неврологические расстройства при алкоголизме / И. В. Дамулин, Т. Е. Шмидт // Неврологический журнал. - 2004. - № 2. - С. 4-10.

2. Пауков В. С. Алкоголизм и алкогольная болезнь // В. С. Пауков, Н. Ю. Беляева, Т. М. Воронина // Терапевтический архив. - 2001. - Т. 73, № 2. - С. 65-67.

3. Яхно Н. И. Болезни нервной системы: Руководство для врачей. В 2 т., Т. 1. / Под ред. Н. И. Яхно, Д. Р. Штульмана, П. В. Мельничука. - М. : Медицина, 1995 - С. 598-599.

4. Яновський I. І. Фізіологія людини і тварин. Практикум : навч. посібник / І. І. Яновський, П. В. Ужако. К. : Вища шк., 1991. - 175 с.

5. Халилов М. Х. К характеристике некоторых патохимических сдвигов в крови, тканях печени и головного мозга при экспериментальной алкогольной интоксикации / М. Х. Халилов, Ш. Я. Закихорджаев // Вопр. клиники алкоголизма : сб. науч. тр. - Ташкент, 1983. - С. 38-41. 
6. Adachi J. Alcoholic muscle disease and biomembrane perturbations (review) / J. Adachi, M. Asano, Y. Ueno, O. Niemelä, K. Ohlendieck, T. J. Peters, V. R. Preedy // J. Nutr. Biochem. - 2003. - Vol. 14, № 11. P. 616-625.

7. Corsi A. Effect of activity on performance and morphology in ischemic rat slow muscles / A. Corsi, A. L. Granata // J. Exp. Biol. - 1990. - Vol. 152. - P. 265-279.

8. Dekeyser G. J. Chronic alcohol ingestion delays skeletal muscle regeneration following injury / G. J. Dekeyser, C. R. Clary, J. S. Otis // Regenerative Medicine Research. - 2013. - Vol. 1, № 2. - P. 1-12.

9. Fernandez-Sola J. Low-dose ethanol consumption allows streigth recovery in chronic alcoholic myopathy / J. Fernandez-Sola, J. M. Nicolas, E. Sacanella / Q. J. Med. - 2000. - Vol. 93, № 1. - P. 35-40.

10. Preedy V. R. Alcoholic skeletal muscle myopathy: definitions, features, contribution of neuropathy, impact and diagnosis // V. R. Preedy, J. Adachi, G. Veno // Eur. J. Neurol. - 2001. - Vol. 8, № 6. - P. 677-687.

11. Ramstedt M. Alcohol-related mortality in 15 European countries in the post war period / M. Ramstedt // Eur. J. Populat. - 2002. - Vol. 18, № 4. - P. 307-323.

12. Reilly M. E. Protein and mRNA levels of the myosin heavy chain isoforms I, IIa, IIx and IIb in type I and type II fibrepredominant rat skeletal muscles in response to chronic alcohol feeding / M. E. Reilly, G. McKoy, D. Mantle, T. J. Peters, G. Goldspink, V. R. Preedy // J. Muscle. Res. Cell. Motil. - 2000. - Vol. 21, № 8. P. 763-773.

13. Spoth R. Preventive interventions addressing underage drinking: state of the evidence and steps toward public health impact / R. Spoth, M. Greenberg, R. Turrisi // Pediatrics. - 2008. - Vol. 121, № 4. - P. 311-336.

14. Tidball J. G. Mechanisms of Muscle Injury. Repair and Regeneration / J. G. Tidball // Comprehensive physiology. - 2011. - Vol. 1, №. 4. - P. 2029-2062.

15. Vary T. C. Restoration of protein synthesis in heart and skeletal muscle after with drawal of alcohol / T. C. Vary, A. C. Nairn, C. H. Lang // Alcohol. Clin. Exp. Res. - 2004. - Vol. 28, № 4. - P. 517-525.

16. WHO. 2014. World health statistics 2014. - Geneva : World Health Organization. - P. 122-180.

Мельничук Олексій, Мотузюк Олександр. Швайко Світлана, Зай Світлана. Динаміка розвитку прогресивної втоми ізольованого нативного musculus gastrocnemius medialis в алкоголізованих щурів. В роботі проаналізовано динаміку розвитку прогресивної втоми ізольованого нативного musculus gastrocnemius medialis в алкоголізованих щурів під час тетанічного скорочення. Дослідження проведено на 305 -місячних шурах самцях лінії Wistar: алкоголізовані щурі $(n=15)$, інтактні щурі $(n=15)$. Реєстрація тетанічного скорочення ізольованого м'язового препарату здійснена в ізометричному режимі, під час його безпосередньої електричної стимуляції. Результати дослідження показали, що динаміка розвитку прогресивної втоми ізольованого нативного musculus gastrocnemius medialis в алкоголізованих щурів, порівняно з інтактними щурами, достовірно не змінюється, і як і в контролі, має асиметричний характер.

Ключові слова: алкогольна інтоксикація, алкоголізовані щурі, м'язова втома, ізольований м'язовий препарат, m. gastrocnemius.

Мельничук Алексей, Мотузюк Александр, Швайко Светлана, Зай Светлана. Динамика развития прогрессивной усталости изолированного нативного musculus gastrocnemius medialis в алкоголизированных крыс. В работе анализировалась динамика развития прогрессивной усталости изолированного нативного musculus gastrocnemius medialis в алкоголизированных крыс во время тетанического сокращения. Исследования проводились на 30 5-месячных крысах-самцах линии Wistar: алкоголизированные крысы (n=15), интактные крыы $(\mathrm{n}=15)$. Регистрация тетанического сокращения изолированного мышечного препарата осуществлялась в изометрическом режиме, во время непосредственной электрической стимуляции мышечного препарата. Результаты исследования показали, что динамика развития прогрессивной усталости изолированного нативного musculus gastrocnemius medialis в алкоголизированных крыс, сравнительно с интактными крысами, достоверно не изменяется, и как и в контроле, имеет асимметрический характер.

Ключевые слова: алкогольная интоксикация, алкоголизированные крысы, мышечная усталость, изолированый мышечный препарат, m. gastrocnemius.

The article acted to the editorial board in 10.02 .2015 